\title{
Os trânsitos e as influências estrangeiras na alimentação da cidade de São Paulo (1800-1830)
}

\section{Transits and foreign influences on eating habits of the city of São Paulo (1800-1830)}

Rafaela Basso ${ }^{1}$

A cidade de São Paulo vivenciou nas primeiras décadas do século XIX um movimento de expansão econômica e populacional. Isto fez com que a região se tornasse um entreposto de distribuição de mercadorias e estivesse, cada vez mais, vinculada à dinâmica internacional de circulação de mercadorias e capitais. A disponibilidade de novos estabelecimentos, animada pela multiplicação dos serviços urbanos, transformou os espaços da cidade e foi responsável por mudanças na alimentação da cidade.

À medida que o século XIX avançava, portanto, veremos que parte considerável dos paulistanos foi confrontada com novos comportamentos alimentares, que englobaram desde o surgimento de estabelecimentos onde se podia fazer refeições, como as casas de pastos, até a difusão de novos gêneros comestíveis e bebidas disponíveis à venda no mercado local para consumo na hora ou para serem preparados em casa. Isso sem falar nas novas práticas alimentares, cada vez mais associadas a uma ideia de sociabilidade, observadas intra e extramuros. A proposta da presente comunicação é destacar as diferentes influências estrangeiras nas transformações dos hábitos alimentares dos paulistanos nas primeiras décadas dos Oitocentos, através da discussão tanto dos produtos quanto dos estabelecimentos surgidos no período. Utilizaremos como fontes principais para aprofundarmos nossa compreensão sobre as atividades mercantis ligadas à alimentação a documentação da imprensa periódica.

Palavras-chave: São Paulo; século XIX; influências estrangeiras; casas de pasto.

Keywords: São Paulo; $19^{\text {th }}$ century; foreign influences; "casas de pasto".

1 Doutora em História pela Universidade Estadual de Campinas (Unicamp), diretora de Cestão e Preservação de Documentos e Informação do Arquivo Central da Unicamp. 